\title{
FENOMENA SOSIOLOGI OBJEK WISATA SEJARAH DI YOGYAKARTA: SUATU KAJIAN TENTANG SOSIOLOGI PARIWISATA
}

\author{
Oleh: V. Indah Sri Pinasti ${ }^{1}$
}

\begin{abstract}
Abstrak
Pariwisata sebagai salah satu penggerak di sector ekonomi dapat menjadi solusi bagi pemerintah dalam meningkatkan pembangunan ekonomi.Salah satu wilayah yang memiliki potensi besar dalam industri wisata adalah Yogyakarta.Penelitian ini bertujuan untuk mengetahui dan mendeskripsikan fenomena sosiologi yang terjadi pada objek wisata sejarah di Yogyakarta meliputi objek wisata Candi Prambanan, Kotagede, Keraton Yogyakarta, Tamansari dan Benteng Vredeburg.
\end{abstract}

Kata Kunci: fenomena, sosiologi pariwisata

\section{A. Pendahuluan}

Pariwisata sebagai salah satu penggerak di sektor ekonomi dapat menjadi solusi bagi pemerintah dalam meningkatkan pembangunan ekonomi. Sektor pariwisata tidak hanya menyentuh kelompok-kelompok ekonomi tertentu tetapi dapat menjangkau ekonomi kalangan bawah. Masyarakat sekitar objek-objek wisata dapat mendirikan berbagai kegiatan ekonomi, misalnya tempat penginapan, layanan jasa (transportasi, informasi), warung, dan lain-lain.Kegiatan-kegiatan tersebut dapat menambah pendapatan masyarakat, sehingga tingkat pengangguran dapat ditekan.

Pengembangan pariwisata berbasis potensi wisata sejarah dan budaya merupakan salah satu alternatif tujuan wisata.Suasana kehidupan budaya yang jauh dari kehidupan modern memberikan kesan yang berbeda bagi wisatawan.Pengembangan wisata berbasis peninggalan sejarah sangat tepat dilakukan di wilayah Yogyakarta. Yogyakarta pernah mendapatkan gelar The League of Historical City dari UNESCO bersama-sama dengan 88 kota besar bersejarah seperti Kyoto, Paris, London, Boston, dan sebagainya. Oleh karena itu upaya pemerintah untuk mengembangkan objek-objek wisata sejarah dan budaya

${ }^{1}$ Staf Pengajar Jurusan Pendidikan Sejarah FIS UNY 
di kota Yogyakarta perlu mendapatkan dukungan. Terlebih dengan dikembangkannya potensi-potensi wisata yang ada di daerah tentu akan memberikan peningkatan pada kehidupan perekonomian masyarakat setempat.

Yogyakarta selain terkenal sebagai kota pelajar juga terkenal dengan potensi wisata yang dimiliki. Potensi-potensi baik berupa keindahan panorama alam maupun kebudayaannya. Banyak sekali objek wisata yang terkait dengan sejarah dan kebudayaan. Sebagai pusat kebudayaan Jawa, Yogyakarta sangat kaya peninggalan sejarah masa lalu baik dari zaman klasik atau masa pengaruh Hindu Budha maupun pengaruh dari pemerintah kolonial Hindia Belanda. Peninggalan dari zaman klasik tersebar di berbagai wilayah Yogyakarta antara lain kompleks Candi Prambanan di Sleman maupun berbagai macam situs Hindu Budha di wilayah Bantul seperti situs Payak dan sebagainya. Peninggalan dari masa Islam juga tidak kalah banyaknya antara lain situs Kotagede, keratin Yogyakarta, maupun Tamansari. Dengan adanya objek wisata sejarah ini tentu saja mempunyai dampak terhadap kehidupan masyarakat.

\section{B. Tinjauan Pustaka}

\section{Tinjauan Fenomena}

Fenomena berasal dari Yunani phainonena (yang berakar kata panein berarti menampak) sering digunakan untuk merujuk ke semua objek yang masih dianggap eksternal dan secara paradigmatiK harus disebut objektif (dalam arti belum menjadi bagian dari subjektivitas konseptial manusia). Fenomena adalah gejala dalam situasi alaminya yang kompleks, yang hanya mungkin menjadi bagian dari alam kesadaran manusia sekomprehensif apapun manakala telah direduksi ke dalam suatu parameter yang terdefinisikan sebagai fakta, dan yang demikian terwujud sebagai suatu realitas. Dalam fakta selalu terkandung subjektivitas manusia, sedangkan dalam fenomena yang ada hanyalah objektifitas 
yang alami, dan karena itu tentunya sangat kompleks sehingga sulit diliput oleh kemampuan manusia yang rasional. ${ }^{2}$

\section{Tinjauan Interaksi Sosial}

Manusia merupakan makhluk sosial yang tidak dapat hidup tanpa bantuan orang lain. Oleh karena itu manusia perlu berinteraksi dengan manusia lainnya tanpa adanya interaksi sosial, tidak mungkin ada kehidupan bersama.Interaksi sosial merupakan hubungan-hubungan sosial yang dinamis yang menyangkut hubungan antara orang per orangan, antara kelompok dan kelompok manusia, maupun antara orang per oramgan dengan kelompok manusia. ${ }^{3}$

Suatu interaksi sosial tidak akan mungkin terjadi apabila tidak memenuhi 2 syarat, yaitu adanya kontak sosial dan komunikasi. Kontak sosial adalah hubungan antara satu pihak dengan pihak lain yang merupakan awal terjadinya interaksi sosial, dan masing-masing pihak saling bereaksi meski tidak harus bersentuhan secara fisik. Kontak sosial dapat terjadi walau dua pihak hanya saling berhadapan atau bertatap muka.

Syarat kedua adanya interaksi sosial adalah adanya komunikasi soaial. Komunikasi adalah seorang memberikan tafsiran pada perilaku orang lain (berwujud pembicaraan, gerak-gerik badaniyah atau sikap). Perasaan-perasaan apa yang ingin disampaikan oleh orang tersebut. Orang yang bersangkutan kemudian memberikan reaksi terhadap perasaan yang ingin disampaikan oleh orang lain tersebut. Adanya komunikasi tersebut, sikap-sikap, dan perasaan-perasaan satu kelompok manusia atau orang per seorangan dapat diketahui oleh kelompokkelompok lain atau orang lain. Hal itu kemudian merupakan bahan untuk menentuan reaksi apa yang akan dilakukannya. ${ }^{4}$

2 Burhan Bungin. 2003. Metodologi Penelitian Kualitatif Aktualisasi Metodologis ke Arah Ragam Varian Kontemporer. Jakarta: PT Raja Grafindo Persada, hlm. 17-18

3 Soerjono Soekanto. 2005. Sosiologi Suatu Pengantar. Jakarta: PT. Grafindo Persada, hlm. 21

${ }^{4}$ Ibid, hlm. 67 


\section{Tinjauan Teori Sosiologi \\ 1. Teori Fenomenologi}

Fenomenologis studi tentang cara di mana fenomena hal-hal yang kita sadari muncul kepada kita dan cara yang paling mendasar dari pemunculannya adalah sebagai suatu aliran pengalaman-pengalaman indrawi yang berkesinambungan yang kita terima melalui panca indra kita. Fenomenologi tertarik dengan pengidentifikasian masalah dari dunia pengalaman indrawi yang bermakna, suatu hal yang semula terjadi di dalam kesadaran individual kita secara terpisah dan kemudian secara kolektif, di dalam interaksi antara kesadaran.

\section{Interaksionisme Simbolik}

Dalam pandangan interaksionisme simbolik manusia buka dilihat sebagai produk yang ditentukan oleh struktur dan situasi objektif, tetapi paling tidak sebagian merupakan factor-faktor yang bebas.Interaksionisme simbolik dilakukan dengan menggunakan bahasa, sebagai satu-satunya symbol yang terpenting dan melalui isyarat.

Rumusan yang paling ekonomis dari asumsi-asumsi interaksionis datang dari karya Herbert Blumer ${ }^{5}$

a. Manusia bertindak terhadap sesuatu atas dasar makna-makna yang dimiliki benda-benda itu bagi mereka

b. Makna-makna itu merupakan hasil dari interaksi sosial dalam masyarakat manusia

c. Makna-makna dimodifikasikan dan ditangani melalui proses penafsiran yang digunkan oleh setiap individu dalam keterlibatannya dengan tanda-tanda yang dihadapinya.

Pada intinya, teori ini menyatakan bahwa tanggapan seseorang tidak dibuat secara langsung terhadap tindakan lain, tetapi didasarkan pada 'makna” yang diberikan terhadap tindakan orang lain tersebut. Interaksi antar individu dijembatani oleh simbol-simbol, interpretasi atau saling berusaha untuk saling memahami maksud dan tindakan masing-masing individu.

5 Craib Ian. 1992. Teori-Teori Sosial Modern dari Parsons sampai Habermas. Jakarta: CV Rajawali, hlm. 128 - 129 


\section{Teori Penyimpangan Sosial (Deviasi Sosial)}

Perilaku menyimpang dianggap menjadi sumber masalah sosial. Penggunaan konsep perilaku menyimpang secara tersirat mengandung makna bahwa ada jalur baku yang harus ditempuh, yaitu jalur pranata sosial. Perilaku yang tidak melalui jalur tersebut berarti telah menyimpang.Oleh karena jalur yang harus dilalui adalah jalur pranata sosial merupakan tolak ukur yang digunakan untuk melihat suatu perilaku menyimpang atau tidak. ${ }^{6}$

Perilaku menyimpang juga merupakan perilaku dari warga masyarakat yang dianggap tidak sesuai dengan kebiasaan, tata aturan atau norma sosial yang berlaku.

Perilaku menyimpang secara umum dapat digolongkan sebagai berikut ${ }^{7}$ :

a. Tindakan yang nonconform, yaitu perilaku yang tidak sesuai dengan nilai-nilai atau norma-norma yang ada

b. Tindakan yang anti sosial atau asosial yaitu tindakan yang melawan kebiasaan masyarakat atau kepentingan umum

c. Tindakan-tindakan kriminal yaitu tindakan-tindakan yang nyata-nyata telah melanggar aturan-aturan hukum tertulis dan mengancam jiwa atau keselamatan orang lain.

\section{Teknik Pengumpulan Data}

Teknik pengumpulan data bertujuan untuk memperoleh data dengan caracara yang sesuai penelitian sehingga peneliti akan memperoleh data yang lengkap. Penelitian ini menggunakan sumber data yang diperoleh secara lisan dan tertulis. Adapun teknik pengumpulan data yang digunakan dalam penelitian ini sebagai berikut:

6 Soetomo. 2008. Masalah Sosial dan Upaya Pencegahannya. Yogyakarta: Pustaka Pelajar, hlm. 94

7 J. Dwi Narwoko. 2010. Sosiologi Teks Pengantar dan Terapan. Jakarta: Kencana, hlm. 101 


\section{Observasi}

Observasi adalah dasar semua ilmu pengetahuan. Para ilmuwan hanya dapat bekerja berdasarkan data, yaitu fakta mengenai dunia kenyataan yang diperoleh melalui observasi. ${ }^{8}$ Dalam hal ini peneliti menggunakan teknik observasi langsung non partisipan, di mana peneliti hanya mengamati kegiatan yang dilakukan oleh masyarakat sekitar objek wisata.

\section{Wawancara}

Metode wawancara adalah suatu metode pengumpulan data dengan jalan tanya jawab yang dilakukan secara sistematis dan berlandaskan kepada tujuan penelitian. Peneliti menggunakan metode wawancara bertahap, metode ini bersifat sistematik karena pokok permasalahan yang akan ditanyakan pada responden telah dipersiapkan sebelumnya. Wawancara yang dilakukan peneliti ditujukan kepada beberapa responden seperti para pengunjung, pedagang dan masyarakat sekitar lokasi wisata, serta karyawan lokasi wisata.

\section{Dokumentasi}

Metode dokumentasi adalah cara atau metode untuk mendapatkan dan mengumpulkan data dengan menggunakan dokumen, catatan atau laporan dari suatu kejadian atau kegiatan. Dokumentasi merupakan pengambilan data yang diperoleh melalui dokumen-dokumen. Peneliti menggunakan teknik dokumentasi untuk melengkapi atau menambah data yang didapatkan melalui wawancara maupun observasi. Peneliti menggunakan berbagai sumber seperti buku-buku, foto, artikel yang relevan dengan penelitian.

\section{E. Sumber Data}

Sumber data merupakan subjek di mana data diperoleh. Penelitian kualitatif mempunyai sumber data utama yang bersumber dari kata-kata dan tindakan, selebihnya adalah data tambahan seperti dokumen dan lain-lain.

8 Nasution. 2003. Metode Penelitian Naturalistik Kualitatif. Bandung: Tarsito, hlm. 56 


\section{Sumber data primer}

Sumber data primer merupakan data yang diperoleh dengan cara menggali sumber asli secara langsung melalui responden, melalui wawancara dan pengamatan langsung di lapangan. Sumber data primer dalam penelitian ini adalah masyarakat sekitar lokasi wisata, para pedagang di lokasi wisata, dan karyawan lokasi wisata.

\section{Sumber data sekunder}

Sumber data sekunder merupakan sumber tidak langsung yang mampu memberikan tambahan serta penguatan terhadap suatu penelitian. Sumber data sekunder ini diperoleh melalui dokumentasi dan studi kepustakaan dengan bantuan media cetak dan internet.

\section{F. Teknik Cuplikan/Sampling}

Populasi dan sampling merupakan salah satu elemen yang sangat vital dalam metodologi penelitian sebab populasi sampling sangat berpengaruh terhadap data yang diperoleh. Sampel dalam penelitian kualitatif diambil untuk mewakili situasi sosial yang diteliti. Peneliti mengambil purposive sampling sebagai teknik pengambilan sampel pada penelitian ini. Hal ini dimaksudkan untuk memperoleh data sesuai objek penelitian.

\section{G. Validitas Data}

Agar penelitian menjadi valid dan dapat dipertanggungjawabkan maka harus ada validitas data. Dalam penelitian ini, peneliti menggunakan teknik triangulasi data. Teknik triangulasi adalah sebuah teknik pemeriksaan keabsahan data dengan memanfaatkan sesuatu yang lain di luar data itu untuk keperluan pengecekan atau sebagai pembanding terhadap data itu. ${ }^{9}$ Teknik triangulasi yang digunakan dalam penelitian ini adalah triangulasi sumber dan triangulasi metode.

9 Moleong, Lexy J. 2006. Metodologi Penelitian Kualitatif. Bandung: Remaja Rosdakarya, hlm. 330 


\section{H. Teknik Analisis Data}

Miles dan Huberman mengemukakan bahwa aktivitas dalam analisis data kualitatif dilakukan secara interaktif dan berlangsung secara terus-menerus sampai tuntas, sehingga datanya sudah jenuh. Langkah-langkah dalam analisis kualitatif menurut Miles dan Hubermen antara lain:

\section{Pengumpulan Data}

Pengumpulan data dilakukan dengan menggali data dari berbagai sumber, yaitu dengan wawancara, pengamatan yang kemudian dituliskan dalam catatan lapangan, memanfaatkan dokumen lainnya yang relevan.

\section{Reduksi data (data reduction)}

Reduksi data dilakukan dengan merangkum dan memilih pokok-pokok dari data yang diperoleh dari lapangan sehingga data tersebut terlihat lebih jelas dan mempermudah peneliti untuk menyusun data selanjutnya.

\section{Penyajian Data (data display)}

Penyajian data berupa susunan teks yang bersifat naratif. Melalui penyajian data, maka data terorganisasikan, dan tersusun dalam pola hubungan sehingga akan semakin mudah dipahami. ${ }^{10}$

\section{Kesimpulan (conclusion) dan Verifikasi}

Setelah dilakukan berbagai tahapan proses pengumpulan data, reduksi data, penyajian data, maka langkah selanjutnya adalah melakukan penulisan kesimpulan dengan tujuan untuk menjawab rumusan masalah. Penulisan ini diuraikan secara detail mengenai gambaran permasalahan yang terdapat di lapangan. Langkah tersebut dilanjutkan dengan pengujian validitas data menggunakan bukti-bukti yang valid, dalam hal ini peneliti menggunakan teknik triangulasi data.

\section{Hasil Penelitian}

Penelitian ini mengambil beberapa lokasi objek wisata di Daerah Istimewa Yogyakarta yang masing-masing mewakili masanya. Candi Prambanan

10 Sugiyono. 2008. Metode Penelitian Kuantitatif, Kualitatif, dan R\&D. Bandung : Alfabeta, hlm. 249 
merupakan bangunan yang didirikan pada masa pengaruh kebudayaan Hindu Budha, Kotagede, Keraton Yogyakarta, dan Tamansari merupakan peninggalan masa Islam, dan Benteng Vredeburg merupakan peninggalan dari masa kolonial.

\section{Candi Prambanan}

Candi Prambanan terletak 13 km dari kota Klaten ke arah barat dan 17 km dari Yogyakarta ke arah timur. Kata Prambanan berasal dari kata brahma, Brahman, brahmana, dan atman, yang didirikan sebagai tempat beribadah umat Hindu dan perabuan raja terbesar di Indonesia.Candi ini dibangun pada abad ke-9 oleh Rakai Pikatan dari Dinasti Sanjaya yang beragama Hindu untuk dipersembahkan kepada istrinya Pramodawardhani yang beragama Budha.

Dalam perkembangannya saat ini Candi Prambanan difungsikan sebagai objek wisata sekaligus tempat ibadah pemeluk Hindu.Pada awalnya masyarakat tidak setuju terhadap rencana pemerintah untuk menjadikan Candi Prambanan sebagai objek wisata, karena masyarakat menganggap Candi Prambanan sebagai candi keramat. Mereka khawatir jika tempat suci tersebut dijadikan tempat wisata akan memengaruhi kehidupan lingkungan sekitarnya yang nantinya akan mendatangkan malapetaka dan kerugian bagi warganya. Bahkan pada awalnya sempat terjadi konflik terkait dengan rencana penggusuran permukiman penduduk dan sekolah yang akan dijadikan sebagai taman dan tempat parkir. Namun pada akhirnya masyarakat menyetujui rencana pemerintah itu.

Dengan dijadikannya Candi Prambanan sebagai objek wisata maka terjadi berbagai macam perubahan. Proses sosial yang terjadi di kawasan wisata Candi Prambanan ini dapat dilihat dari kerjasama antara masyarakat sekitar candi. Sebagian besar karyawan Candi Prambanan merupakan masyarakat yang berasal dari sekitar candi.Artinya kehadiran Candi Prambanan membuka lapangan kerja baru bagi masyarakat yang tinggal di sekitar candi. Untuk menarik pengunjung,

pihak pengelola Candi Prambanan bekerjasama dengan Dinas Pariwisata menyelenggarakan sendratari Ramayana yang dipertunjukkan setiap bulan purnama.Para penarinya meliputi para penari professional dan didukung oleh masyarakat sekitar. Selain itu masyarakat sekitar juga memiliki mata pencaharian baru misalnya sebagai pedagang yang menjual pernak-pernik dan oleh-oleh khas 
candi, berjualan minuman dan makan ringan, dan lain-lain.Dengan dibukanya Candi Prambanan sebagai tempat wisata ternyata telah mengurangi tingkat pengangguran dan menyumbang pada perekonomian bagi kas pemerintah daerah. Dapat dikatakan kawasan wisata ini hamper tidak pernah kehabisan pengunjung.

Di kawasan Candi Prambanan, proses sosial yang berupa konflik dapat dikatakan sangat jarang terjadi. Sebagaimana penuturan Ibu Maryati, seorang pedagang yang telah berjualan selama 19 tahun di kawasan ini, antara pedagang satu dengan yang lainnya tidak ada persaingan yang tajam, sementara antara pedagang dengan karyawan candi juga selalu terjalin hubungan yang baik, saling menghargai, dan bersikap ramah.

\section{Kotagede}

Kotagede merupakan kota lama peninggalan kerajaan Mataram Islam. Beberapa objek yang dapat dilihat di Kotagede anatara lain makam Raja-raja Mataram, sentra industri kerajinan perak, dan wisata kuliner.

Industri seni kerajinan perak yang memberikan identitas dan ciri khas Yogyakarta sampai saat ini masih terkonsentrasi di kawasan sekitar Kotagede lama, bekas kuthanegara Kerajaan Mataram Islam abad ke-16 dan 17.Saat ini industri perak utamanya menempati wilayah-wilayah Kelurahan Prenggan dan Kelurahan Purbayan, dan Kelurahan Jagalan. Menurut catatan Kanwil Deperindag Propinsi DIY, terdapat 95 unit usaha industri kerajinan perak, 75 unit usaha di Kotagede dan 20 unit usaha di Kabupaten Bantul yang mempekerjakan 1.269 tenaga kerja. Sejak tahun 1970-an kerajinan perak produksi Kotagede telah diminati wisatawan mancanegara baik yang berbentuk perhiasan, peralatan rumah tangga, ataupun aksesoris penghias. Secara umum hasil kerajinan perak di kota ini terbagi dalam empat jenis, yaitu aneka perhiasan (kalung, gelang, cincin, anting), miniatur seperti kapal dan candi, dekorasi atau hiasan dinding, dan aneka kerajinan lainnya.

Saat ini usaha kerajinan perak mengalami penurunan karena generasi mudanya cenderung tidak berminat pada kerajinan perak, mahalnya bahan baku, berkurangnya wisatawan asing yang khawatir dengan situasi keamanan Indonesia, 
belum berkembangnya desain kerajinan, dan masih buruknya manejemen pemasaran.

Sebagai objek wisata Kotagede memberikan berbagai dampak bagi masyarakat. Dampak positifnya antara lain melestarikan kebudayaan, menambah pemasukan daerah dan devisa negara, bertambahnya lowongan pekerjaan, meningkatkan taraf ekonomi masyarakat, dan dapat mengurangi pengangguran. Di samping dampak positif terdapat pula berbagai macam dampak negatif, diantaranya: 1) konflik antara aliran Muhammadiyah dan NU. Muhammadiyah tidak setuju dengan adat kejawen yang divisualisasikan melalui ziarah kubur, sedangkan NU tidak mempermasalahkan hal tersebut karena tidak musrik; 2) masuknya budaya-budaya asing yang kurang sesuai dengan adat istiadat yang ada di masyarakat Kotagede; 3) timbulnya konflik antar pedagang perak yang ada di Kotagede.

\section{Keraton Yogyakarta}

Keraton Yogyakarta dibuka sebagai objek wisata sejak masa pemerintahan Sri Sultan Hamengku Buwono IX. Sebagai asset kebudayaan dan pusat kebudayaan Jawa, Keraton Yogyakarta selayaknya dibuka sebagai objek wisata sehingga berbagai segi yang ada di keraton dan sekitarnya mendapatkan pengaruh dan timbal balik dari hal tersebut.

Dibukanya Keraton Yogyakarta sebagai objek wisata memberikan pengaruh yang sangat besar bagi masyarakat dalam bidang perekonomian yaitu dengan terciptanya banyak lapangan kerja seperti pemandu, penjual koran, penjual makanan, penjual minuman, souvenir, dan lain-lain. Dalam waktu-waktu tertentu misalnya pada musim liburan pendapatan masyarakat dapat meningkat dari biasanya. Hal ini tentu dapat meningkatkan taraf kehidupan dan kesejahteraan masyarakat.

Di sisi lain kekhawatiran muncul atas dibukanya Keraton Yogyakarta sebagai objek wisata. Masyarakat sekitar merasa bahwa wibawa keraton sebagai pusat budaya dan sebagai pusat pemerintahan justru semakin menurun.Kraton kehilangan kesakralannya dan tata krama dalam lingkungan keraton mulai terabaikan. 


\section{Tamansari}

Tamansari pertama kali dijadikan objek wisata sekitar tahun 1970-an. Tamansari memiliki nilai seni bangunan yang sangat artistik dan unik serta mengandung nilai sejarah yang sangat tinggi.Pada awalnya tamansari merupakan sebuah tempat untuk pemandian para puteri raja.Saat ini tamansari telah beralih fungsi sebagai tempat wisata budaya.

Dengan dibukanya Tamansari sebagai objek wisata terjadi perubahan yang sangat menonjol dalam bidang ekonomi.Penduduk sekitar yang dulunya bermatapencaharian sebagai pedagang di pasar tradisional banyak di antaranya yang kemudian beralih profesi sebagai pegawai di lokasi wisata, antara lain sebagai guide Tamansari karena mengetahui seluk beluk dan sejarah Tamansari.

Namun demikian dampak lain yang merupakan penyimpangan sosial juga terjadi di kawasan wisata Tamansari. Tamansari banyak digunakan oleh anakanak sekolah untuk tempat membolos dengan berbagai aktivitas mereka. Mereka merokok, minum-minuman keras, corat-coret tembok, berpacaran di loronglorong Tamansari tanpa mendapat pengawasan sama sekali. Lingkungan fisik Tamansari dari waktu ke waktu juga semakin kotor karena ulah para pengunjung yang tidak bertanggung jawab. Banyak dari pengunjung yang mengotori dan mencoret-coret tembok dengan tulisan-tulisan kotor. Hal ini tentu merusak nilai budaya yang ada di Tamansari.

\section{Benteng Vredeburg}

Benteng Vredeburg merupakan bangunan peninggalan zaman colonial Belanda yang kemudian oleh pemerintah Indonesia dilestarikan dengan mempertahankan struktur bangunan kuno tersebut sebagai objek wisata budaya. Keberadaan Benteng Vredeburg sebagai objek wisata budaya didukung oleh berbagai faktor, antara lain: bangunan benteng yang sangat klasik, aksesibilitas yang relative mudah, maupun pergelaran budaya yang sering dipertunjukkan di sekitar Benteng. Misalnya pergelaran budaya etnik yang menampilkan tari-tarian tradisional dari Sabang sampai Merauke, dan Harmonight Jogja Java Carnival.

Hadirnya Benteng Vredeburg sebagai kawasan wisata budaya menyebabkan terjadinya proses perubahan sosial, antara lain: 
1. Musisi jalanan dulunya mayoritas adalah mahasiswa, saat ini musisi jalanan didominasi anak jalanan.

2. Munculnya berbagai macam pedagang di sekitar kawasan benteng.

Proses sosial yang bersifat asosiatif di kawasan Benteng berupa kerja sama antara para pedagang kaki lima misalnya saling meminjamkan uang kecil, saling menjagakan barang dagangan bila pedagang tersebut ada kepentingan lain; muncul paguyuban-paguyuban tukang parker, pedagang asongan, dan tukang becak. Paguyuban tersebut dinamakan "Roso Selamet" yang mengadakan pertemuan setiap tiga bulan sekali.

Di samping proses sosial yang bersifat asosiatif, muncul pula proses sosial yang bersifat disosiatif, yaitu suatu proses tidak adanya keselarasan antar individu atau pun sekelompok orang, misalnya kompetisi, konflik, dan kontroversi. Beberapa proses disosiatif di sekitar kawasan Benteng Vredeburg antara lain:

1. Konflik antar preman atau pengamen. Kerap terjadi perkelahian antar preman atau pengamen di sekitar Benteng Vredeburg khususnya pada malam hari. Hal ini karena preman yang mabuk kehilangan kendali dan kesadaran dalam bertingkah laku yang kemudian tindakan itu mengganggu orang-orang di sekitar benteng Vredeburg.

2. Konflik antara Pedagang Kaki Lima (PKL) dengan petugas Satpol PP. Penertiban yang dilakukan oleh Satpol PP biasanya sekitar pukul 17.00 - 18.00 WIB atau pada malam hari pukul 22.00 WIB. Penertiban dilakukan karena PKL tersebut melanggar aturan dengan berdagang di depan kantor pemerintahan yang berada di kawasan sekitar Benteng Vredeburg, sementara pemerintah telah menyediakan tempat untuk para PKL di Pasar Sore. Denda yang dikenakan pada PKL apabila terjaring Satpol PP berkisar antara Rp. 150.000,- sampai Rp. 200.000,- dengan jaminan KTP.

Bentuk-bentuk penyimpangan sosial yang terjadi di sekitar kawasan Benteng Vredeburg antara lain:

1. Kumpulan pemabuk di depan gerbang benteng sering mengganggu pengunjung yang ingin menikmati suasana malam Jogja. Tingkah laku pemabuk yang di luar kendali sering membuat keonaran apalagi setelah lewat tengah malam 
maka pengunjung akan mendapati sekelompok preman yang mabuk-mabukan di depan Benteng Vredeburg.

2. Bagi orang Jawa khususnya Jogjakarta yang masih menjunjung tinggi adatistiadat, perempuan akan dianggap melakukan penyimpangan sosial jika keluar pada malam hari. Padahal di sekitar Benteng Vredeburg banyak perempuan berkeliaran bahkan datang ke Benteng dengan pasangan mereka. Perilaku tersebut dianggap sangat tidak sopan dan tidak pantas dilakukan oleh seorang perempuan. Melihat fenomena tersebut sangat tidak sesuai dengan pola adat Jawa yang sebenarnya sehingga perilaku tersebut dianggap menyimpang.

3. Kadang-kadang pengamen sering memaksa pengunjung untuk memberikan uang recehnya padahal pengunjung tersebut tidak berkenan. Hal ini sering menimbulkan keributan karena pengamen seenaknya sendiri minta bayaran bahkan ada pengamen apabila tidak diberi uang akan memaki atau melakukan tindak kekerasan. Tentu saja hal ini sangat mengganggu ketertiban dan kenyaman pengunjung.

4. Wilayah sekitar Benteng Vredeburg memang sangat memesona pada malam hari. Di lain pihak pada malam hari kesempatan untuk terjadinya penyimpangan sosial sangat tinggi sehingga tidak jarang aksi kriminal yang menimpa pengunjung seperti aksi pencopetan sering terjadi. Jika tidak hati-hati menjaga barang bawaannya terutama dompet akan menjadi korban pencopetan. Pencurian helm juga sering terjadi.

\section{J. Penutup}

Berdasarkan pemaparan yang telah disampaikan dari bab sebelumnya dapat diambil beberapa kesimpulan tentang fenomena sosiologis pada objek wisata sejarah di Yogyakarta. Fenomena sosiologi tersebut berupa proses sosial baik yang asosiatif maupun disosiatif. Pada umumnya lokasi wisata tersebut memberikan perubahan yang besar dalam bidang ekonomi karena terbukanya lapangan kerja baru dan terjadi pula mobilitas sosial.Selain itu juga muncul fenomena sosiologi berupa konflik dan penyimpangan sosial. 
Pada lokasi wisata Candi Prambanan terjadi berbagai macam perubahan. Dibukanya Candi Prambanan sebagai objek wisata sejarah telah membuka lapangan kerja baru bagi masyarakat di sekitar candi, antara lain sebagai pedagang, sebagai karyawan di lokasi wisata, dan sebagai penari latar pada pertunjukan sendratari Ramayana. Proses disosiatif di kawasan ini jarang terjadi, yang ada justru kerja sama dan hubungan baik anta pedagang, pengunjung, dan karyawan candi.

Kotagede memiliki daya tarik sebagai sentra industri perak sekaligus sebagai bekas kutanegara Kerajaan Mataram Islam yang masyarakatnya masih melestarikan tradisi lama.Perubahan positif yang terjadi dalam masyarakat terkait status Kotagede sebagai objek wisata sejarah adalah lestarinya budaya tradisional, bertambahnya lapangan pekerjaan, meningkatnya taraf ekonomi masyarakat, dan berkurangnya pengangguran. Dampak negatifnya antara lain adanya konflik antar pedagang perak karena persaingan bisnis dan masuknya budaya-budaya asing yang kurang sesuai dengan adat istiadat yang ada di masyarakat Kotagede.

Dibukanya Keraton Yogyakarta sebagai objek wisata berpengaruh besar bagi masyarakat dalam bidang perekonomian karena terciptanya banyak lapangan kerja baru. Namun demikian di sisi lain ada kekhawatiran dari masyarakat bahwa wibawa keratin sebagai pusat budaya semakin menurun. Keraton akan kehilangan kesakralannya dan tata karma dalam lingkungan kraton mulai terabaikan.

Sama halnya dengan ketiga lokasi wisata yang telah disebutkan di atas, maka perubahan masyarakat di kawasan wisata Tamansari yang sangat menonjol adalah dalam bidang ekonomi. Penyimpangan sosial yang marak dijumpai di kawasan ini adalah digunakannya kawasan wisata ini sebagi tempat untuk membolos dengan berbagai aktivitasnya, merokok, minum-minuman keras, coratcoret tembok, dan sebagai tempat untuk berpacaran.

Di Benteng Vredeburg hal yang sama juga terjadi. Proses asosiatif berupa kerja sama antara pedagang kaki lima, paguyuban tukang parker, pedagang asongan, dan tukang becak. Sedangkan proses disosiatif adalah konflik-konflik yang terjadi antara preman atau pengamen, konflik antara pedagang kaki lima dengan petugas satpol PP. 


\section{DAFTAR PUSTAKA}

Burhan Bungin. 2003. Metodologi Penelitian Kualitatif Aktualisasi Metodologis ke Arah Ragam Varian Kontemporer. Jakarta: PT Raja Grafindo Persada.

Craib Ian. 1992. Teori-Teori Sosial Modern dari Parsons sampai Habermas. Jakarta: CV Rajawali.

J. Dwi Narwoko. 2010. Sosiologi Teks Pengantar dan Terapan. Jakarta: Kencana.

Moleong, Lexy J. 2006. Metodologi Penelitian Kualitatif. Bandung: Remaja Rosdakarya.

Nasution. 2003. Metode Penelitian Naturalistik Kualitatif. Bandung: Tarsito.

Soenyoto Oesman. 2008. Pembangunan dan Pemberdayaan Masyarakat. Yogyakarta: Pustaka Pelajar.

Soerjono Soekanto. 2005. Sosiologi Suatu Pengantar. Jakarta: PT. Grafindo Persada.

Soetomo. 2008. Masalah Sosial dan Upaya Pencegahannya. Yogyakarta: Pustaka Pelajar.

Sugiyono. 2008. Metode Penelitian Kuantitatif, Kualitatif, dan R\&D. Bandung : Alfabeta. 